Acta vet. scand. $1984,25,365-377$.

From the Department of Obstetrics and Gynaecology and Department of Clinical Chemistry, College of Veterinary Medicine, Swedish University of Agricultural Sciences, Uppsala, Sweden.

\title{
SOME REPRODUCTIVE AND CLINICAL ASPECTS OF ENDOTOXINS IN COWS WITH SPECIAL EMPHASIS ON THE ROLE OF PROSTAGLANDINS*
}

\author{
By \\ Gunnar Fredriksson
}

\begin{abstract}
FREDRIKSSON, GUNNAR: Some reproductive and clinical aspects of endotoxins in cows with special emphasis on the role of prostaglandins. Acta vet. scand. 1984, 25, 365-377. - Endotoxin from Salmonella typhimurium was administered intravenously to 3 cows. It produced an immediate increase in blood prostaglandin metabolite levels causing either luteolysis or a temporary drop in progesterone concentrations depending on the degree of prostaglandin synthesis. The clinical effects on heart rate, respiratory rate, ruminal contraction rate, body temperature and other general signs were studied. The cows showed a transient increase in heart and respiratory rate and a decrease in ruminal activity. The temperature responded by a small initial decrease and a secondary increase. Other symptoms included muscular weakness and shivering, excessive salivation and diarrhoea. Plasma Ca levels showed a direct decrease and then slowly increased to initial levels in the course of several days. The role of endotoxins in Gram-negative infections and their mode of action on the body are discussed with special emphasis on the role of prostaglandins on reproductive function.
\end{abstract}

luteolysis; hypocalca emia.

Gram-negative infections in cattle are not uncommon and are most frequently located in the digestive tract, in the uterus or in the udder. In lactating cows infections in the udder may cause clinical signs resembling parturient paresis and when endotoxins from Gram-negative bacteria are administered similar signs occur (Carroll et al. 1963). Endotoxins induce production of different prostaglandins (Harper et al. 1980, Fredriksson et al. 1985), but treatment with prostaglandin synthesis inhibitors

* This study was supported by grants from the Swedish Council for Forestry and Agricultural Research. 
prior to the administration of endotoxin will eliminate most of the symptoms (Fletcher \& Ramwell 1977, Moore et al. 1981). Since prostaglandin $\mathrm{F}_{2 \alpha}$ acts luteolytically in most domestic species (Horton \& Poyser 1976) an increased synthesis and release will affect reproduction. The purpose of this study was to investigate the ability of an endotoxin from Salmonella typhimurium, to influence reproductive functions and also to assess some general clinical effects in cows.

\section{Animals}

\section{MATERIAL AND METHODS}

Three crossbred cows (nos. 1, 2, 3) of Swedish Friesian and Swedish Red and White Breed with normal oestrous cyclicity were used. They were quartered individually and fed according to Swedish standards. The oestrus was synchronized by injection of $0.5 \mathrm{mg}$ cloprostenol (Estrumat vet, LEO, Sweden) given i.m. at intervals of 11 days.

\section{Endotoxin}

The S. typhimurium endotoxin (lipopolysaccharide; LPS) was extracted by the hot phenol-water method from batch-grown cultures of formaldehyde-killed S. typhimurium SH4809, and the LPS was further purified and characterized as described previously (Svenson et al. 1978, Lindberg et al. 1983). The endotoxin was dissolved in saline and administered i.v. into the jugular vein of 3 cows (body weigths 575,460 and $545 \mathrm{~kg}$, respectively) on 3 occasions in doses of $0.5 \mu \mathrm{g} / \mathrm{kg}$ (on day 8 of the oestrous cycle), $2.5 \mu \mathrm{g} / \mathrm{kg}$ and $5.0 \mu \mathrm{g} / \mathrm{kg}$ (on day 9 of the oestrous cycle). The interval between the 1st and 2 nd injections was 40 days and between the 2nd and 3rd injections 70 days.

\section{Blood sampling}

From the start of the synchronization until the beginning of the experiment $10 \mathrm{ml}$ of blood was collected daily for progesterone analysis. During the first $30 \mathrm{~h}$ after the injection of endotoxin an hourly blood sampling schedule was used. The sampling was then continued 5 times daily during 14 days. Jugular vein blood samples were withdrawn into heparinized Vacutainer tubes (Becton-Dickinson, USA) and centrifuged directly. Plasma was removed and stored at $-20^{\circ} \mathrm{C}$ until hormone analysis. 
For counts of total leukocytes EDTA Vacutainer tubes were used. Blood sampling was performed daily 4 days before the administration of endotoxin, every $3 \mathrm{~h}$ during the first $30 \mathrm{~h}$ and then continued daily during 1 week.

\section{Hormone analysis}

The plasma samples were analysed for the content of progesterone and 15-keto-13,14-dihydro- $\mathrm{PGF}_{2 \alpha}$ using radioimmunoassays (Bosu et al. 1976, Kindahl et al. 1976). The area under the 15-keto-13,14-dihydro-PGF ${ }_{2 \alpha}$ response curve for the first $10 \mathrm{~h}$ following endotoxin injection was calculated with an electronic integrator (Digiplan, Kontron Messgeräte, FRG).

\section{Calcium and phosphorus analysis, leukocyte count}

Plasma Ca was determined in an atomic absorption spectrophotometer (model 603, Perkin-Elmer, Connecticut, USA) by a method presented by Trudeau \& Freier (1967). The determination of $\mathrm{P}_{\text {in }}$ was performed by a method described by Haya \& Ui (1966). A photometer was used for final readings (LKB 2074, Clinicon AB, Bromma, Sweden).

Blood leukocytes were counted in a celloscope (Linson Instrument AB, Stockholm, Sweden). Differential counting of 200 cells was performed after staining. Values for various leukocytes are given as absolute values.

Reference values for each parameter studied were calculated for each individual animal using the data gathered prior to injection of endotoxin. The pre-experimental mean values for Ca and $P$ of each animal were based on analysis of 20 plasma samples taken at different times, for leukocyte count on 5 samples and for clinical parameters on observations during 5 days. Mean and standard errors were calculated.

\section{RESULTS}

During the first hours after the injection of endotoxin the prostaglandin metabolite levels increased from $100-200 \mathrm{pmol} / \mathrm{l}$ to $1000-7000 \mathrm{pmol} / \mathrm{l}$. The peak response lasted for $5-10 \mathrm{~h}$ and was then followed by decreasing levels of $200-500 \mathrm{pmol} / \mathrm{l}$ during an additional $5-10 \mathrm{~h}$, when pre-experimental baseline values were again reached (Figs. 1 and 2). The area under the prostaglandin metabolite curve versus dose of endotoxin injected is plotted in Fig. 3. 


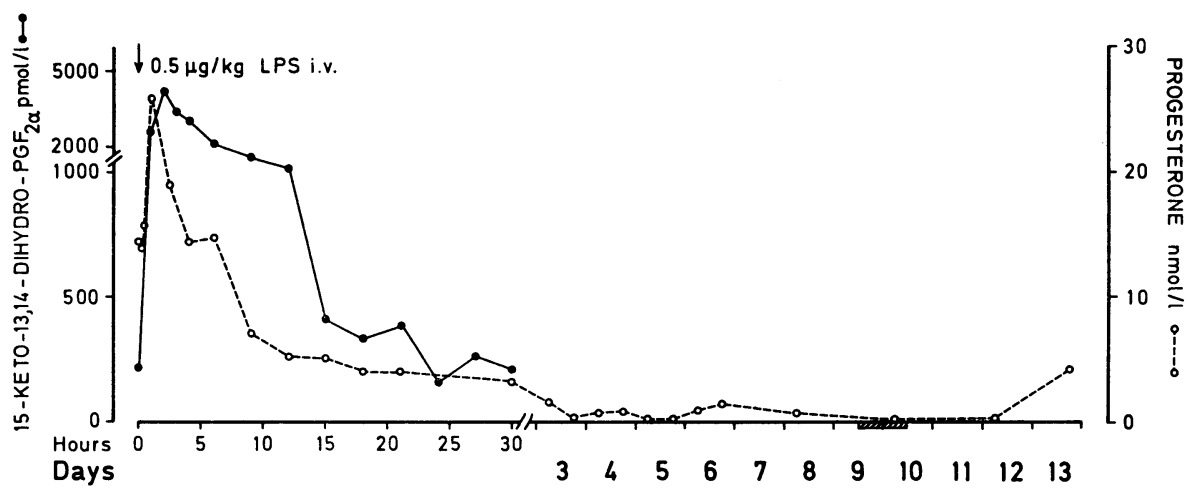

F i g u r e 1. Peripheral blood plasma level of 15-keto-13,14-dihydro$\mathrm{PGF}_{2 \alpha}\left(\mathrm{O}_{-}\right)$and progesterone $(\mathrm{O} \ldots \mathrm{-}$ ) in cow 1. Solid arrow indicates the time of endotoxin injection into the jugular vein $(0.5 \mu \mathrm{g} /$ $\mathrm{kg}$ ) on day 8 of the oestrous cycle. Horizontal hatched bar denotes the time of rectally determined ovulation.

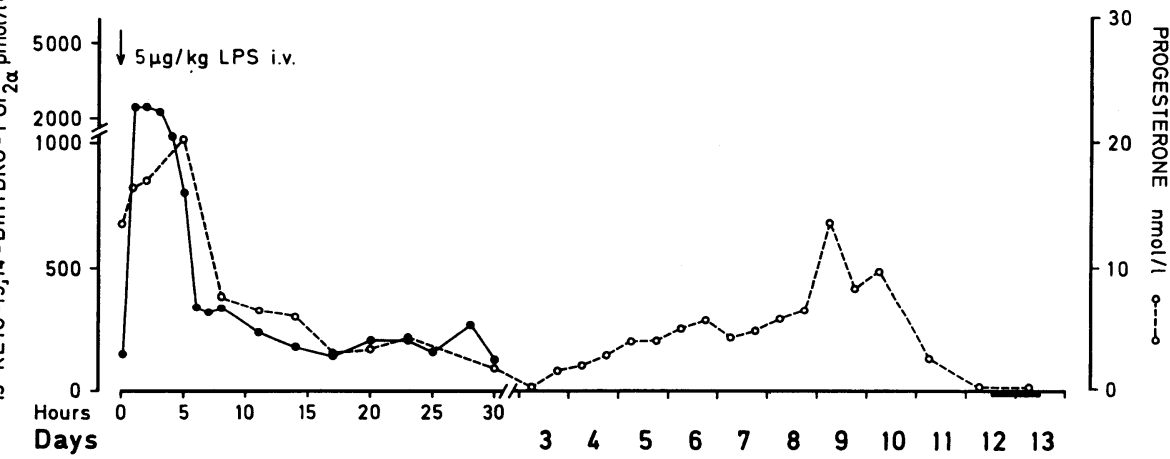

F i g u r e 2. Peripheral blood plasma level of 15-keto-13,14-dihydro$\mathrm{PGF}_{2 \alpha}(\mathrm{O}-\mathrm{O})$ and progesterone $\left(\mathrm{O}-\mathrm{O}_{\mathrm{O}}\right)$ in cow 3. Solid arrow indicates the time of endotoxin injection into the jugular vein $(5.0 \mu \mathrm{g} /$ $\mathrm{kg}$ ) on day 9 of the oestrous cycle. Horizontal black bar denotes the time of oestrus.

Progesterone values decreased rapidly in all cases (Figs. 1 and 2). In cow no. 1 progesterone levels decreased to $<1 \mathrm{nmol} / \mathrm{l}$ for all 3 doses tested, taking approximately 2 days at 0.5 and 2.5 $\mu \mathrm{g} / \mathrm{kg}$ and $18 \mathrm{~h}$ at $5.0 \mu \mathrm{g} / \mathrm{kg}$. In cows 2 and 3 progesterone levels did not decrease to $<1 \mathrm{nmol} / \mathrm{l}$ (except 1 observation in cow 3 at $5.0 \mu \mathrm{g} / \mathrm{kg}$ ). In both these animals the levels rose again and a final progesterone drop occurred at the expected time of luteolysis (Fig. 2). Cow 1 retained low progesterone levels $(<1 \mathrm{nmol} / \mathrm{l}$, 


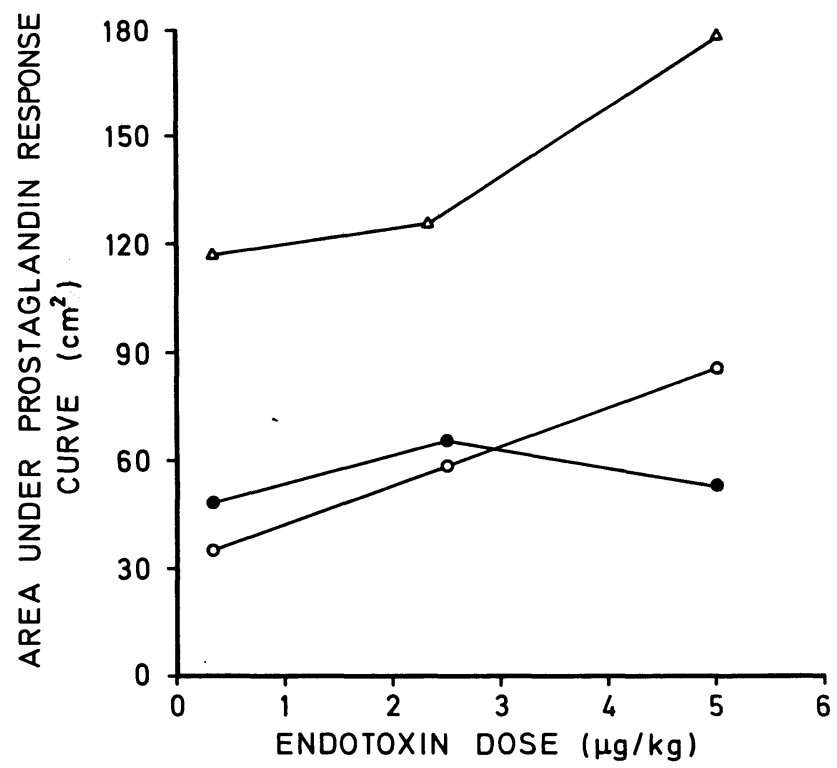

$\mathrm{Figure} 3$. The dose of endotoxin is given on the $\mathrm{x}$-axis. The response of $\mathrm{PGF}_{2 \alpha}$ is plotted on the $\mathrm{y}$-axis and is estimated as the area under the curve of measured levels of 15-keto-13,14-dihydro-PGF ${ }_{2 \alpha}$ during the first $10 \mathrm{~h}$ after injection. $\triangle$ represents cow $1, \mathrm{O}$ cow 2 and cow 3 .

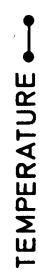

\section{$\downarrow 2.5 \mu \mathrm{g} / \mathrm{kg}$ LPS i.v.}
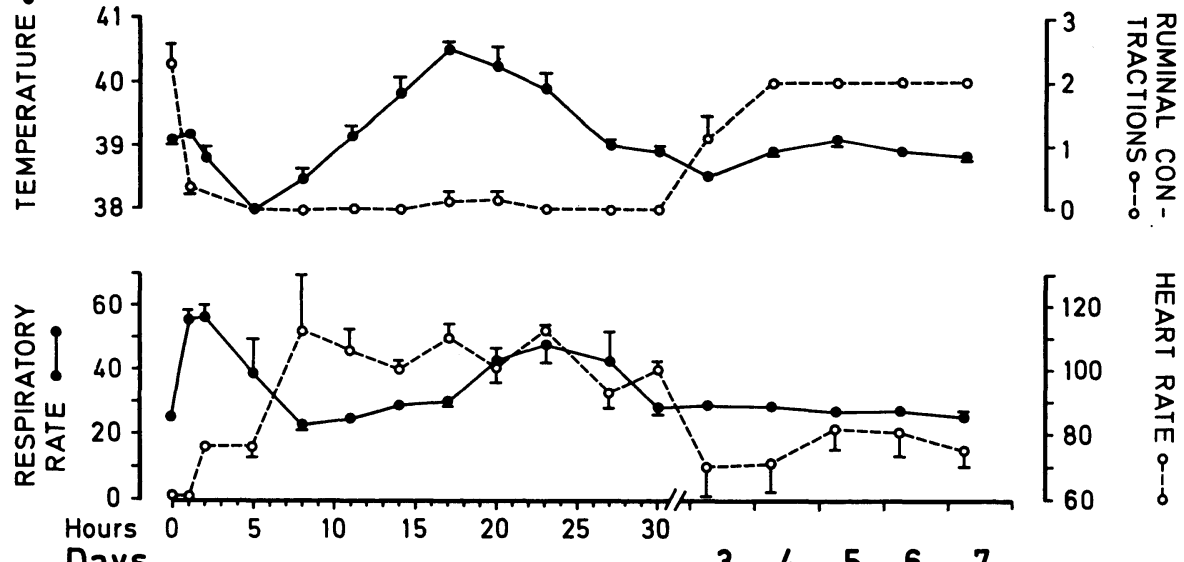

Hours

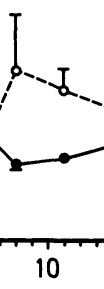

F i g u re 4. Effect of i.v. administration of endotoxin $(2.5 \mu \mathrm{g} / \mathrm{kg})$ on temperature (O-O) ruminal contraction rate $(0 \ldots-0)$ (upper panel), respiratory rate (O-O) heart rate (0... O) (lower panel). Mean values of 3 cows \pm s.e.m. Solid arrow indicates the time of endotoxin injection into the jugular vein. 
mostly $<0.1)$ until concentrations started to rise $3-4$ days earlier than in cows 2 and 3 indicating a shorter inter-ovulatory interval. Cow 1 did not show clear signs of oestrus but ovulation was detected rectally. Oestrus at expected times was detected both by external signs and by rectal palpation in cows 2 and 3 .

The body temperature response showed an initial decrease with a minimum around $5 \mathrm{~h}$ after the administration of endotoxin and a secondary increase with a maximum after $15-20 \mathrm{~h}$ (Fig. 4 and Table 1 ). After $25-30 \mathrm{~h}$ the temperature again returned to initial values. The higher the dose given, the lower the minimum and the higher the maximum temperature.

T a b l e 1. Influence of endotoxins on body temperature.

\begin{tabular}{ccccc}
\hline $\begin{array}{c}\text { Endotoxin } \\
\text { dose } \mu \mathrm{g} / \mathrm{kg}\end{array}$ & Before injection & & \multicolumn{2}{c}{ After injection } \\
\cline { 2 - 3 } \cline { 5 - 5 } & $\overline{\mathrm{x}} \pm$ s.e.m. & & Minimum $\overline{\mathrm{x}} \pm$ s.e.m. & Maximum $\overline{\mathrm{x}} \pm$ s.e.m. \\
\hline 0.5 & $38.8 \pm 0.1$ & & $38.4 \pm 0.4$ & $40.2 \pm 0.2$ \\
2.5 & $39.1 \pm 0.1$ & & $38.0 \pm 0.1$ & $40.5 \pm 0.2$ \\
5.0 & $38.9 \pm 0.2$ & & $37.5 \pm 0.3$ & $40.7 \pm 0.4$ \\
\hline
\end{tabular}

Ruminal contractions ceased almost directly after the injection of endotoxin (Fig. 4). They could be monitored again after $8 \mathrm{~h}$ at $0.5 \mu \mathrm{g} / \mathrm{kg}$ and after $30 \mathrm{~h}$ at 2.5 and $5.0 \mu \mathrm{g} / \mathrm{kg}$. Activity was normalized after $15 \mathrm{~h}$ at $0.5 \mu \mathrm{g} / \mathrm{kg}$ and after $3-4$ days at 2.5 and $5.0 \mu \mathrm{g} / \mathrm{kg}$.

An increased respiratory rate with peak values of $60-80$ per minute was registered during $4-8$ hours (Fig. 4). Another rise but less pronounced was seen during the secondary increase in temperature. Then respiratory rate returned to normal.

The heart rate increased more slowly during the first hours (Fig. 4) and reached maximal levels of 90-130 beats per min. The heart rate returned to normal values after $48 \mathrm{~h}$ at 0.5 and $2.5 \mu \mathrm{g} / \mathrm{kg}$ and after $5-6$ days at $5.0 \mu \mathrm{g} / \mathrm{kg}$.

Other clinical observations included presence of excessive salivation, transient diarrhoea, anorexia and signs of muscular weakness and light muscle shivering during the first $24-48 \mathrm{~h}$. Some of the cows preferred recumbent position. The skin temperature on the back was subjectively colder.

Already in the first sample after the administration of endotoxin a drop in plasma Ca concentration was monitored (Fig. 5). The higher the dose of endotoxin the more pronounced and more 

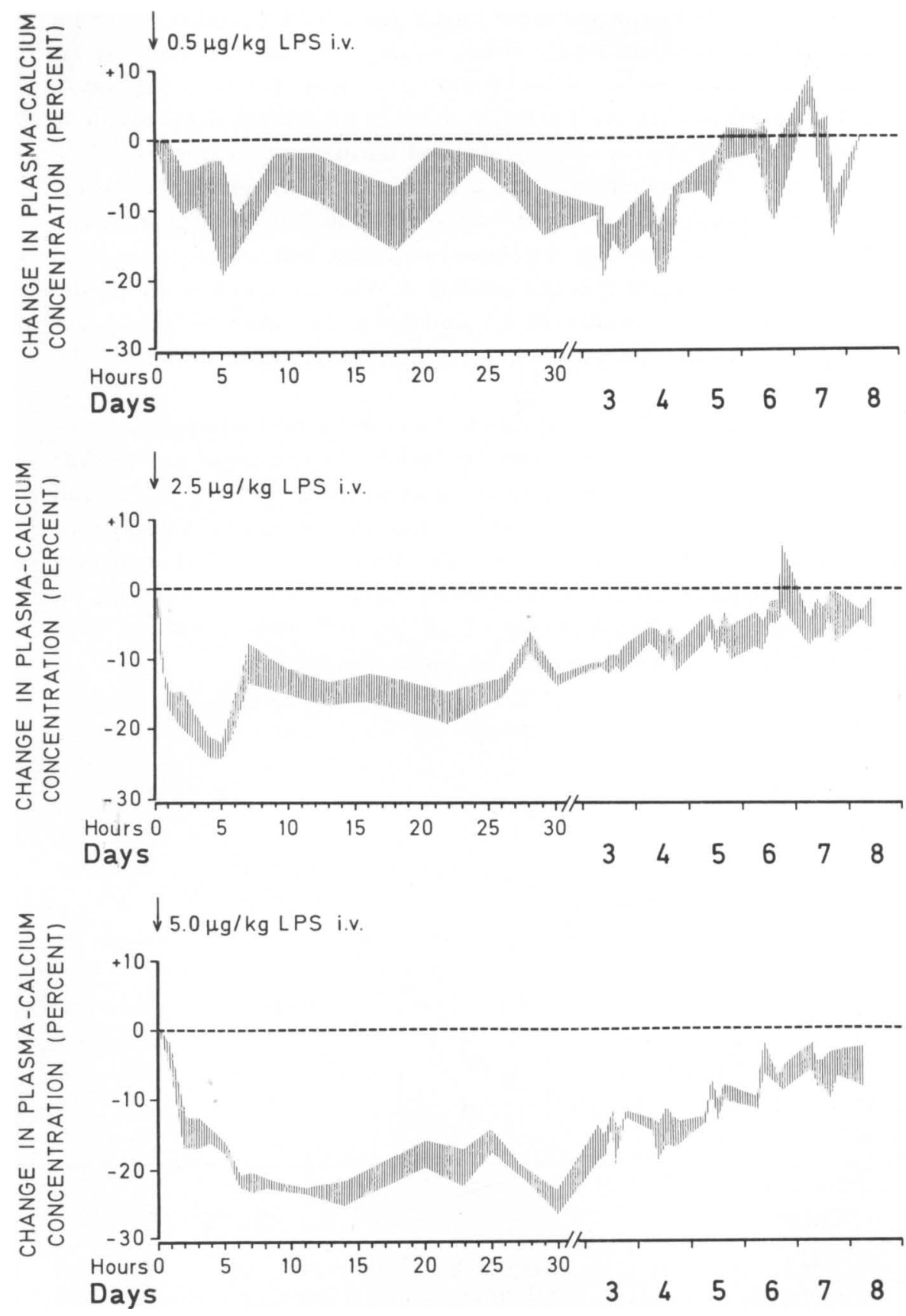

Figure 5. Percentage change in plasma Ca concentration after administration of endotoxin $(0.5 \mu \mathrm{g} / \mathrm{kg}$, upper panel; $2.5 \mu \mathrm{g} / \mathrm{kg}$, middle panel; $5.0 \mu \mathrm{g} / \mathrm{kg}$, lower panel). Mean levels of 3 cows \pm s.e.m. Zero is $2.65 \mathrm{mmol} / \mathrm{l} \mathrm{Ca}$. Solid arrow indicates the time of endotoxin injections into the jugular vein. 
long-lasting was the decrease in Ca levels. At $0.5 \mu \mathrm{g} / \mathrm{kg}$ the Ca levels fluctuated around $-10 \%$ with large standard errors of the mean and reached pre-experimental concentrations on day 5 after injection. At $2.5 \mu \mathrm{g} / \mathrm{kg}$ there was an initial drop of $25 \%$ but after $10 \mathrm{~h}$ the Ca levels stabilised temporarily around - $15 \%$ and then slowly increased back to reach pre-experimental levels on day 7-8. At $5.0 \mu \mathrm{g} / \mathrm{kg}$ the decrease was $20-25 \%$ during the first 2 days, followed by a gradual increase, but pre-experimental levels had not been reached on day 8 . The standard error of the mean was much smaller at 2.5 and $5.0 \mu \mathrm{g} / \mathrm{kg}$ than at $0.5 \mu \mathrm{g} / \mathrm{kg}$. $P_{\text {in }}$ was also measured but significant changes could not be observed.

The number of leukocytes decreased quickly after treatment (Fig. 6). The higher the dose on endotoxin the more severe was the decrease. The neutrophils decreased to $1-5 \%$ of initial values during the first $10-20 \mathrm{~h}$, whereas lymphocytes decreased only to $20-30 \%$ during the same time. On the 2nd day preexperimental numbers were observed again. At 0.5 and $5.0 \mu \mathrm{g} / \mathrm{kg}$ there was a marked increase of all the parameters during days $3-5$. This was not so visible at $2.5 \mu \mathrm{g} / \mathrm{kg}$.
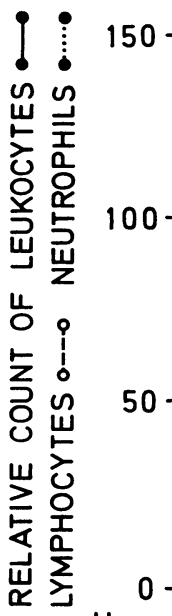

Hours

Days

$$
\downarrow 2.5 \mu \mathrm{g} / \mathrm{kg} \text { LPS i.v. }
$$

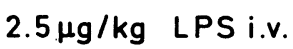

Fig u r e 6. Leukocyte lymphocyte count $(\mathrm{O} \ldots \mathrm{O})$ after administration of endotoxin (2.5 $\because \mathrm{g} / \mathrm{kg})$. Mean values of 3 cows. The variation is based on the absolute number of the different cell types at each occasion. Solid arrow indicates the time of endotoxin injection into the jugular vein. 


\section{DISCUSSION}

After i.v. administration of endotoxin sufficient quantities of prostaglandins were produced to affect luteal function. Depending on the amount of prostaglandins released (Fig. 3) either luteolysis with subsequent shortening of the cycle (Fig. 1) or a temporal depression of progesterone levels (Fig. 2) occurred. The estimated prostaglandin metabolite production seems to be individually related (Fig. 3) ; cow no. 1 having the highest release of prostaglandins, as a matter of fact she released more prostaglandins at $0.5 \mu \mathrm{g} / \mathrm{kg}$ than the others did after $5 \mu \mathrm{g} / \mathrm{kg}$. There is also a slight tendency to a dose-dependent relation, although this is not as obvious as reported in the goat (Fredriksson et al.1985).

The progesterone production of the corpus luteum is considered to be responsible for the maintenance of pregnancy at least during the first two thirds of gestation in the cow (Estergreen et al. 1967). The present results suggest that a Gram-negative infection can elicit pronounced prostaglandin-mediated effects on reproductive functions provided that enough endotoxin comes into contact with prostaglandin synthesizing cells. The end result may be altered lengths of oestrous cycles or abortions.

There is direct and indirect evidence that prostaglandins play a role in the pathophysiology of endotoxins (Veenendaal et al. 1980). The clinical symptoms observed in the presented cows accord closely with earlier studies in cows and other species (Nachreiner et al. 1972, Griel et al. 1975, Elmore et al. 1978). Administration of prostaglandin synthesis inhibitors prevents most of the effects of endotoxins but not all of them (van Miert et al. 1982). One of the prostaglandins produced is $\mathrm{PGF}_{2 \alpha}$, with its effects on reproduction, but also other types of arachidonic acid metabolites are formed. Experimental infusions with $\mathrm{PGE}_{2}$ produces effects on e.g. heart rate (Nakano 1973), bronchial muscle tone (Smith 1976), temperature (Skarnes et al. 1981), as as well as diarrhoea (Roberts 1976). $\mathrm{PGE}_{2}$ is also reported to decrease serum Ca levels in dairy cows, whereas $\mathrm{PGF}_{2} \alpha$ does not influence serum Ca levels (Luthman et al. 1983). Hypocalcaemia is seen after administration of endotoxins to cows (Griel et al. 1973), but also after experimental udder infections with Gramnegative bacteria (Zarkover et al. 1972). The hypocalcaemia is believed to be a step in the process of detoxification of the endotoxins (Skarnes 1970). The clinical signs found in this study, i.e. muscle incoordination, cold skin temperature on the back, 
unwillingness or inability to stand, are early symptoms of hypocalcaemia in cattle. The plasma Ca levels also decrease to concentrations found in hypocalcaemia in cattle (Simesen 1980) at 2.5 and $5.0 \mu \mathrm{g} / \mathrm{kg}$ (Fig. 5). Hypocalcaemia in connection with a Gram-negative infection, e.g. in the udder, not only requires adequate Ca-therapy but also use of prostaglandin synthesis inhibitors in order to prevent the prostaglanin-mediated effects of endotoxins. Also other authors have discussed the role of endotoxins in the pathogenesis of coliform mastitis although without stressing the possible role of prostaglandins (Eberhart et al. 1979, Hill et al. 1979, Frost et al. 1980, Frost \& Hill 1982, Verhejden et al. 1982). The clinical signs seen in the cows in this study give an indication of endogenous $\mathrm{PGE}_{2}$ production, but this parameter is in itself unsatisfactory to measure.

The effects on the cellular constituents of the blood could be due to a shift of leukocytes from circulation to the marginated pool (Athens et al. 1961). Elevated levels of corticoids are also seen after administration of endotoxins (Griel et al. 1975). Corticoids will surely contribute to the leukopenia (Carrol et al. 1964). In experimental coliform mastitis a similar leukopenia is observed at a stage of the infection which would correspond to resorption of endotoxins (Zarkower et al. 1972).

It should be pointed out that the same animals were used 3 times with different doses of endotoxin. Endotoxins are known to be very potent antigens (Culbertson 1980), and induction of tolerance using frequent repetitive administration of endotoxin eliminates the clinical response (van Miert et al. 1982). Immunological factors were not taken into consideration, but it should be noted that the clinical as well as hormonal responses studied are correlated to the dose given. The response is also individually related. The prostaglandin response after i.v. administration of endotoxin is very rapid and probably due to the action of the toxic lipid A part of the lipopolysaccharide molecule. It could be characterized as an immediate, general cell response to the endotoxins. Perhaps there is not time for the protective immunological mechanisms to act and prevent the pathophysiological effects of the endotoxin.

\section{ACKNOWLEDGEMENTS}

I would like to express my sincere thanks to Dr. Stefan B. Svensson, the National Bacteriological Laboratory and Karolinska Institutet, 
Stockholm, for his kind supply of the endotoxin, and to Mrs. Ewa Jonsson, Mrs. Kerstin Lindblad and Mrs. Lena Nordberg for their skilful technical assistance.

\section{REFERENCES}

Athens, J. W., O. P. Haab, S. O. Raab, A. M. Mauer, H. Ashenbrucker, G. E. Cartwright \& M. M. Wintrobe: Leukokinetic studies. IV. The total blood circulating and marginal granulocyte pools and the granulocyte turnover rate in normal subjects. J. clin. Invest. $1961,40,989-995$.

Bosu, W. T. K., L.-E. Edquist, P. Lindberg, K. Martinsson \& E. D. B. Johansson: The effect of various dosages of lynesterol on the plasma level of oestrogens and progesterone during the menstrual cycle in the rhesus monkey. Contraception 1976, 13, $677-684$.

Carroll, E. J., O. W. Schalm \& J. Lasmanis: Experimental coliform (Aerobacter aerogens) mastitis: Characteristics of the endotoxin and its role in pathogenesis. Amer. J. vet. Res. 1964, 25, $720-726$.

Culbertson, R. Jr. \& B. I. Osburn: The biological effects of bacterial endotoxin: A short review. Vet. Sci. Commun. 1980, 4, 3-14.

Eberhart, R. J., R. P. Natzke, F. H. S. Newbould, B. Nonnecke \& R. P. Thompson: Coliform mastitis - A review. J. Dairy Sci. 1979, $62,1-22$.

Elmore, R. G., C. E. Martin \& J. N. Berg: Absorption of Escherichia coli endotoxin from the mammary glands and uteri of early postpartum sows and gilts. Theriogenology 1978, 10, 439_447.

Estergreen, J. L. Jr., O. L. Frost, W. R. Gomes, R. E. Erb \& J. F. Bullard: Effect of ovariectomy on pregnancy maintenance and parturition in dairy cows. J. Dairy Sci. 1967, 50, 1293-1295.

Fletcher, J. R. \& P. W. Ramwell: Modification, by aspirin and indomethacin, of the haemodynamic and prostaglandin releasing effects of E. coli endotoxin in the dog. Brit. J. Pharmac. 1977, $61,175-181$.

Fredriksson, G., H. Kindahl \& L.-E. Edqvist: Endotoxin induced prostaglandin release and corpus luteum function in goats. Anim. Reprod. Sci. 1985, 8 , in press.

Frost, A. J., A. W. Hill \& B. E. Brooker: The early pathogenesis of bovine mastitis due to Escherichia coli. Proc. Royal Soc. London B. $1980,209,431-439$.

Frost, A. J., A. W. Hill \& B. E. Brooker: Pathogenesis of experimental bovine mastitis following a small inoculum of Escherichia coli. Res. Vet. Sci. 1982, 33, 105-112.

Griel, L. C. Jr., A. Zarkower \& R. J. Eberhart: Clinical and clinicopathological effects of Escherichia coli endotoxin in mature cattle. Canad. J. comp. Med. 1975, 39, 1-6.

Harper, M. J. K., R. R. Bodhke \& W. E. Friedrichs: Effect of endotoxin treatment on prostaglandin metabolism by rabbit uterus and oviduct. J. Reprod. Fert. 1980, 58, 101-108. 
Hill, A. W., A. L. Shears \& K. G. Hibbitt: The pathogenesis of experimental Escherichia coli mastitis in newly calved dairy cows. Res. Vet. Sci. 1979, 26, 97-101.

Horton, E. W. \& N. L. Poyser: Uterine luteolytic hormone: A physiological role for prostaglandin $\mathrm{F}_{2 \alpha}$. Physiol. Rev. 1976, 56, 595651.

Itaya, K. \& M. Ui: A new micromethod for the colorimetric determination of inorganic phosphate. Clin. Chim. Acta 1966, 14, 361-366.

Kindahl, H., L.-E. Edqvist, E. Granström \& A. Bane: The release of prostaglandin $\mathrm{F}_{2} \alpha$ as reflected by 15-keto-13,14-dihydroprostaglandin $\mathrm{F}_{2} \alpha$ in the peripheral circulation during normal luteolysis in heifers. Prostaglandins 1976, 11, 871-878.

Lindberg, A. A., G. E. Sheldon \& S. B. Svenson: Induction of endotoxin tolerance with nonpyrogenic $O$-antigenic oligosaccharide-protein conjugates. Infect. Immun. 1983, 41, 883-895.

Luthman, J., S. O. Jacobsson \& H. Kindahl: The influence of prostaglandins on calcium homeostasis in dairy cows. Zbl. Vet. Med. 1983, 30, 1-9.

van Miert, A. S. J. P. A. M., C. T. M. van Duin, J. H. M. Verheijden \& A. J. H.: Schtoman: Endotoxin-induced fever and associated haematological and blood biochemical changes in the goat: the effect of repeated administration and the influence of flurbiprofen. Res. Vet. Sci. 1982, 33, 248-255.

Moore, J. N., H. E. Garner, J. E. Shapland \& D. G. Hatfield: Prevention of endotoxin-induced arterial hypoxaemia and lactic acidosis with flunixin meglumine in the conscious pony. Equine Vet. J. $1981,13,95-98$.

Nachreiner, R. F., M. C. Garcia \& O. J. Ginther: Clinical, hematologic, and blood chemical changes in swine given endotoxin (Escherichia coli) during the immediate postpartum period. Amer. J. vet. Res. 1972 , 33, 2489-2499.

Nakano, J.: Cardiovascular actions. In: Ramwell, P. W. (ed.): The Prostaglandins, vol. 1. Plenum Press, New Work-London 1973, pp. $238-316$.

Robert, A.: Antisecretory, antiulcer, cytoprotective and diarrheogenic properties of prostaglandins. Advances in Prostaglandin and Thromboxane Research 1976, 2, 507-520.

Simesen, M. G.: Calcium, phosphorus, and magnesium metabolism. In: Kaneko, J. (ed): Clinical Biochemistry of Domestic Animals, 3rd edn., Academic Press, New York 1980, pp. 575-648.

Skarnes, R.: Host defense against bacterial endotoxemia: Mechanism in normal animals. J. exp. Med. 1970, 32, 300-315.

Skarnes, R., S. K. Brown, S. S. Hull \& J. A. McCracken: Role of prostaglandin $\mathrm{E}$ in the biphasic fever response to endotoxin. J. exp. Med. 1981, 154, 1212-1224.

Smith, A. P.: Lungs. In: Ramwell, P. W. (ed): The Prostaglandins. Plenum Press, New York-London 1973, pp. 203-218. 
Svenson, S. B. \& A. A. Lindberg: Immunochemistry of Salmonella Oantigens: preparations of an octasaccharide-bovine serum albumin immunogen representative of Salmonella serogroup B Oantigen and characterization of the antibody response. J. Immunol. 1978, 120, 1750-1757.

Trudeau, D. L. \& E.F. Freier: Determination of calcium in urine and serum by atomic absorption spectrophotometry (AAS). Clin. Chem. 1967, 13, 101-114.

Veenendaal, G. H., F. M. A. Woutersen-van Nijnanten, C. T. M. van Duin \& A. S. J. P. A. M. van Miert: Role of circulating prostaglandins in the genesis of pyrogen (endotoxin)-induced ruminal stasis in conscious goats. J. vet. Pharmacol. Therap. 1980, 3, $59-68$.

Verheijden, J. H. M., A. S. J. P. A. M. van Miert, A. J. H. Shotman \& C. T. M. van Duin: Plasma zinc and iron concentrations as measurements for evaluating the influence of endotoxin-neutralinzing agents in Escherichia coli endotoxin-induced mastitis. Amer. J. vet. Res. 1982, 43, 724-728.

Zarkower, A., R. J. Eberhart \& L. Griel: Hypocalcemia and other effects of $\mathrm{E}$. coli endotoxin in cattle. Proc. VII International meeting on disease of cattle. World Association for Buiatrics Congress, London 1972, pp. 339—347.

\section{SAMMANFATTNING}

Effekter av e:zdotoxiner på prostaglandin frisättning, lutealfunktion och klinik hos kor.

Endotoxin från Salmonella typhimurium gavs intravenöst till 3 cyklande kor. Prostaglandinfrisättningen bestämdes genom att mäta 15-keto-13,14-dihydro-PGF ${ }_{2} \alpha$, och gulkroppsfunktionen följdes med progesteronbestämning i plasma. Beroende på mängden frisatt prostaglandin iakttogs antingen luteolys med förkortning av östralcykeln eller en tillfällig sänkning i progesteronnivåerna. Kliniska effekter på hjärt-, andnings- och våmfrekvens samt temperatur registrerades. En övergående ökning av hjärt- och andningsfrekvens samt en sänkning av våmfrekvensen iakttogs. Temperaturen sjönk först för att sedan öka. Bland övriga symtom sågs muskelsvaghet och skakningar, ökad salivering och diarré. Plasma Ca-koncentrationen sjönk omedelbart för att sedan återgå till ursprungsnivåerna under loppet av flera dagar. Endotoxinernas verkningsmekanism i kroppen vid Gram-negativa infektioner diskuteras speciellt med avseende på prostaglandinernas roll.

(Received May 4, 1984).

Reprints may be requested from: G. Fredriksson, the Dept. of Obstetrics and Gynaecology, College of Veterinary Medicine, Swedish University of Agricultural Sciences, S-750 07 Uppsala, Sweden. 